\title{
Purification and biochemical characterization of a secreted group IIA chicken intestinal phospholipase $\mathrm{A}_{2}$
}

\author{
Aida Karray, Fakher Frikha, Yassine Ben Ali, Youssef Gargouri, Sofiane Bezzine*
}

\begin{abstract}
Background: Secretory phospholipase A2 group IIA (IIA PLA2) is a protein shown to be highly expressed in the intestine of mammals. However, no study was reported in birds.

Results: Chicken intestinal group IIA phospholipase $\mathrm{A}_{2}\left(\mathrm{ChPLA}_{2}-\mathrm{II}\right)$ was obtained after an acidic treatment (pH.3.0), precipitation by ammonium sulphate, followed by sequential column chromatographies on Sephadex G-50 and mono-S ion exchanger. The enzyme was found to be a monomeric protein with a molecular mass of around $14 \mathrm{kDa}$. The purified enzyme showed a substrate preference for phosphatidylethanolamine and phosphatidylglycerol, and didn't hydrolyse phosphatidylcholine. Under optimal assay conditions, in the presence of $10 \mathrm{mM} \mathrm{NaTDC}$ and $10 \mathrm{mM} \mathrm{CaCl}_{2}$, a specific activity of $160 \mathrm{U}_{\mathrm{mg}}{ }^{-1}$ for purified ChPLA $\mathrm{A}_{2}-\| \mathrm{A}$ was measured using egg yolk as substrate. The fifteen $\mathrm{NH2}$-terminal amino acid residues of ChPLA $\mathrm{A}_{2}-\mathrm{IIA}$ were sequenced and showed a close homology with known intestinal secreted phospholipases $A_{2}$. The gene encoding the mature ChPLA $A_{2}-I A$ was cloned and sequenced. To further investigate structure-activity relationship, a 3D model of ChPLA - -IIA was built using the human intestinal phospholipase $\mathrm{A}_{2}$ structure as template.

Conclusion: ChPLA2-IIA was purified to homogeneity using only two chromatographic colomns. Sequence analysis of the cloned cDNA indicates that the enzyme is highly basic with a pl of 9.0 and has a high degree of homology with mammalian intestinal PLA - IIA.
\end{abstract}

\section{Background}

Phospholipases $\mathrm{A}_{2}\left(\mathrm{PLA}_{2} \mathrm{~s}\right)$ hydrolyse the $s n-2$ bond of phospholipids resulting in the release of a fatty acid and lysophospholipid. Mammalian PLA $\mathrm{S}_{2}$ are classified in three broad categories of secreted PLA $\mathrm{P}_{2}\left(\mathrm{SLA}_{2}\right)$ and cytosolic PLA $\mathrm{P}_{2}$ which are either calcium dependent as to their catalytic activity, or calcium independent cytosolic $\mathrm{PLA}_{2} \mathrm{~S}$ [1]. Secreted $\mathrm{PLA}_{2} \mathrm{~S}$ are small molecular size proteins $(14-19 \mathrm{kDa})$ with a rigid tertiary structure, having five to eight disulfide bonds that probably confer resistance to proteolysis and thermal denaturation $[1,2]$ with a highly conserved catalytic site and a $\mathrm{Ca}^{2+}$-binding loop. These secreted $\mathrm{PLA}_{2} \mathrm{~S}$ were first detected in snake venom pancreatic juice and in tissues [3]. Secreted $\mathrm{PLA}_{2} \mathrm{~S}$ are also expressed in a number of cell types and present in various body fluids. They participate in the first line in

\footnotetext{
* Correspondence: sofiane_bezzine@yahoo.com

Laboratoire de Biochimie et de Génie Enzymatique des Lipases, ENIS Route de Soukra, 3038 Sfax, University of Sfax -Tunisia
}

antimicrobial defence of the body against bacteria and other pathogens. The extensive literature on $\mathrm{SPLA}_{2} \mathrm{~S}$ in inflammatory diseases has been reviewed [4-11].

The gene of pancreatic $\mathrm{PLA}_{2}$-IB was first isolated in 1986 [12] followed in 1989 by the cloning of non-pancreatic PLA $_{2}$-IIA from rheumatoid arthritic synovial fluid [13] and blood platelets [14]. Together with pancreatic $\mathrm{PLA}_{2}-\mathrm{IB}$, the $\mathrm{PPLA}_{2}$-IIA are the best known and biochemically characterized enzymes. Novel sPLA 2 were identified in the $90^{\text {th }}$ by screening nucleic acid data bases. Up to now, eleven sPLA ${ }_{2}$ s have been cloned: IB, IIA, IIC, IID, IIE, IIF, III, V, X, and XIIA PLA ${ }_{2}$ s together

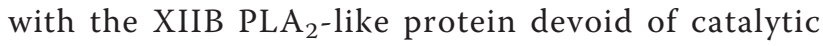
activity $[1,15,16]$. They express different catalytic and binding properties to natural phospholipids $[17,18]$.

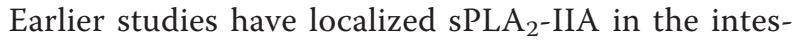
tine $[19,20]$ and in the synovial fluid of patients with rheumatoid arthritis as well as $\mathrm{SPLA}_{2}$ released from platelets $[14,21]$. The concentration levels of $\mathrm{PLA}_{2}$-IIA
C Biomed Central

() 2011 Karray et al; licensee BioMed Central Ltd. This is an Open Access article distributed under the terms of the Creative Commons Attribution License (http://creativecommons.org/licenses/by/2.0), which permits unrestricted use, distribution, and reproduction in any medium, provided the original work is properly cited. 
increase in sera of patients suffering from severe acute inflammatory diseases, such as sepsis and bacterial infections [22,23] and acute pancreatitis [24]. The sPLA 2 -IIA was originally localized in Paneth cells of the rat intestine $[25,26]$ and later on in macrophages [27,28]. The two above mentioned cell types are both involved in the antibacterial response.

Later on it was demonstrated that the PLA $\mathrm{PL}_{2}$-IIA from human and mouse, with high activity on phosphatidylglycerol and bearing cationic properties (pI >9.0), are highly bactericidal against gram positive bacteria [29-33] by perturbing the anionic bacterial cell wall [34]. The bacteria digested by the intestinal $\mathrm{PLA}_{2}$ do not necessarily have to be within the intestinal lumen. Some bacteria specifically invade the intestinal mucosa from the lamina propria, as it has been postulated to occur in

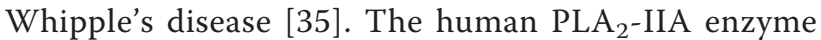
shows low affinity for zwitterionic interfaces, and in the absence of interfacial binding mammalian membrane hydrolysis is not possible [36].

With the growing interest in chicken diseases, such as avian influenza, we recently focused on bird sPLA $\mathrm{A}_{2}$ to further gain some functional and pathological insights. Ben Bacha et al. [37] have biochemically characterized an active thermo stable $\mathrm{PLA}_{2}$-IB from ostrich pancreas $\left(\mathrm{OPLA}_{2}\right)$. Another $\mathrm{PLA}_{2}$-IB was also purified from chicken pancreas and biochemically characterized [38]. It was therefore of interest to further study some biochemical and structural properties of avian non-pancreatic $\mathrm{PLA}_{2}$ to gain more insights into their mode of action on phospholipids and to compare their properties with those of mammalian $\mathrm{PLA}_{2}$. We report here, the purification and some biochemical properties of a secreted $\mathrm{PLA}_{2}$ from chicken intestine (ChPLA $\mathrm{C}_{2}$-IIA). This work reports also the cloning of the corresponding bird PLA $\mathrm{P}_{2}$ CDNA and the comparison of its deduced amino acid sequence with other known mammalian $\mathrm{PLA}_{2}$. A molecular 3D model of ChPLA $\mathrm{C}_{2}$-IIA is also proposed to explain some biochemical differences of ChPLA $\mathrm{C}_{2}$-IIA with other intestinal and pancreatic PLA 2 .

\section{Results and discussion}

\section{Determination of phospholipase activity}

The $\mathrm{PLA}_{2}$ activity was measured titrimetrically at $\mathrm{pH} 9.0$ and at $40^{\circ} \mathrm{C}$ with a pH-stat, under the standard assay conditions as described previously [39], using egg yolk (0.5\% $\mathrm{W} / \mathrm{V}$ ) as substrate, in $30 \mathrm{ml}$ of $150 \mathrm{mM} \mathrm{NaCl}, 10 \mathrm{mM}$ $\mathrm{NaTDC}$ and $10 \mathrm{mM} \mathrm{CaCl}$. The analysis of the purified egg yolk phospholipids by thin layer chromatography revealed the presence of two spots. The major one (90\%) corresponds to the phosphatidylcholine (PC, or lecithin) and the second one (10\%) phosphatidylethanolamine (PE). These two phospholipids were separated by adsorption chromatography on a silica gel column. Elution was performed using stepwise ratios of chloroform/methanol.
We incubated the purified PC or PE samples with ChPLA $_{2}$-IB or ChPLA 2 -IIA respectively and a thin layer chromatography was performed as shown in Figure 1. As expected, ChPLA $\mathrm{A}_{2}$-IB hydrolyzes efficiently PC and PE since the spots of these two phospholipids totally disappeared and a spot of free fatty acid appeared. In contrast, $\mathrm{ChPLA}_{2}$-IIA didn't hydrolyze PC even after a long incubation period. Interestingly, PE was totally hydrolyzed by $\mathrm{ChPLA}_{2}$-IIA similarly to what observed with ChPLA $\mathrm{CH}_{2}$-IB. These analytical results clearly indicate that the hydrolytic activity of ChPLA $\mathrm{C}_{2}$-IIA, measured with $\mathrm{pH}$-stat using egg yolk as substrate, is mainly due to the hydrolysis of the PE fraction.

\section{Purification of ChPLA 2 -IIA}

ChPLA $A_{2}$-IIA was purified from the intestine mucosa using an acidic treatment, ammonium sulfate precipitation, followed by two chromatography steps on Sephadex G-50, and Mono-S Sepharose according to the procedure described in Material and Methods (Figure 2). The main steps of the purification procedures and flow sheet are summarized in Table 1 . The specific activity of pure

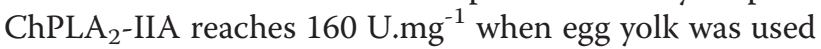
as substrate, at $\mathrm{pH} 9.0$ and at $40^{\circ} \mathrm{C}$, in the presence of 10 $\mathrm{mM} \mathrm{NaTDC}$, and $10 \mathrm{mM} \mathrm{CaCl}_{2}$. The ChPLA 2 -IIA purification yield was about $10 \%$. SDS-PAGE analysis of the purified $\mathrm{ChPLA}_{2}$ IIA eluted from the Mono-S column show that the enzyme exhibited one homogenous band corresponding to an apparent molecular mass of about $14 \mathrm{kDa}$ (Figure 2). The calculated molecular mass, using the amino acid sequence is $13616 \mathrm{Da}$. Furthermore, the calculated isoelectric $\mathrm{pH}$ was equal to $\mathrm{pH} 9.01$.

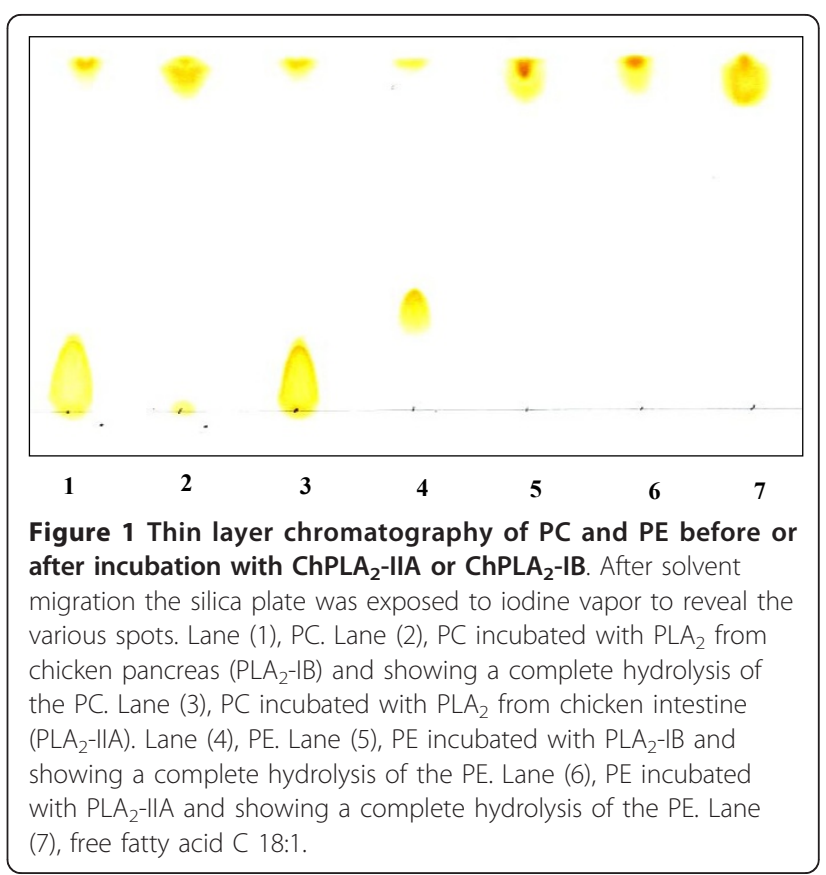



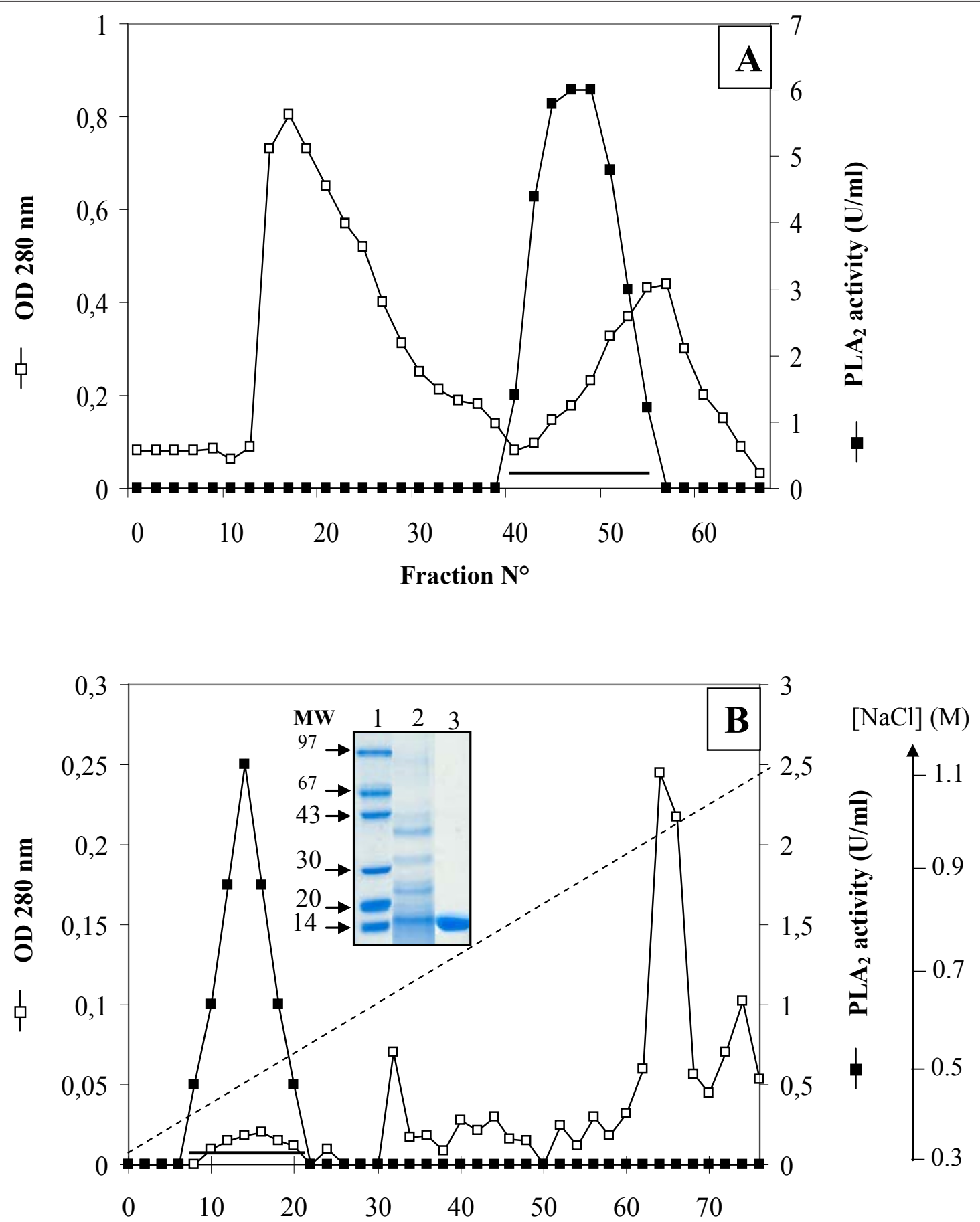

\section{Fraction $\mathbf{N}^{\circ}$}

Figure 2 Purification of ChPLA2-IIA. (A) Gel filtration chromatography of intestinal ChPLA - -IIA on Sephadex G-50. The column (1.5 cm $\times$ $34 \mathrm{~cm}$ ) equilibrated in $20 \mathrm{mM}$ Tris- $\mathrm{HCl}$ buffer $\mathrm{pH} 8.0$ containing $20 \mathrm{mM} \mathrm{CaCl}$ and $2 \mathrm{mM}$ benzamidine. Elution was performed with the same buffer at a flow rate of $40 \mathrm{ml} \cdot \mathrm{h}^{-1}$ and $3 \mathrm{ml}$ samples were collected. ChPLA - -IIA activity was measured as described in Material and methods section using egg yolk emulsion as substrate. The pooled fractions containing the PLA $\mathrm{A}_{2}$ activity were indicated by horizontal line. (B) Mono-S Sepharose chromatography. The column $(5 \mathrm{~cm} \times 2 \mathrm{~cm})$ was equilibrated with $20 \mathrm{mM}$ Tris $\mathrm{HCl}$ buffer pH 8.0 containing $20 \mathrm{mM} \mathrm{CaCl}$ and $2 \mathrm{mM}$ benzamidine; and then washed with the same buffer containing $0.3 \mathrm{M} \mathrm{NaCl}$. Linear salt gradient ( 0.3 to $1 \mathrm{M} \mathrm{NaCl}$, dotted line) was applied to the column; gradient chamber $75 \mathrm{ml} ; 2 \mathrm{ml}$ fraction; flow rate, $40 \mathrm{ml} / \mathrm{h}$. The pooled fractions containing the PLA $\mathrm{A}_{2}$ activity were indicated by horizontal line. SDS-PAGE (15\%) analysis of pure ChPLA 2 -IIA was inserted in Figure 2B. Lane 1, molecular mass markers (MM); Lane 2, $15 \mu \mathrm{g}$ of

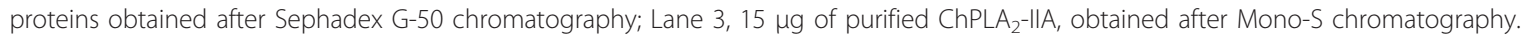


Table 1 Flow sheet of chicken intestinal phospholipase $A_{2}$ purification

\begin{tabular}{|c|c|c|c|c|c|}
\hline Purification Step & Total Activity (U) ${ }^{a}$ & Total Protein $(\mathrm{mg})^{\mathbf{b}}$ & Yield (\%) & Specific activity (U/mg) & Purification Factor \\
\hline $\begin{array}{c}\text { Extraction } \\
\text { (pH 8.5) }\end{array}$ & 250 & 5520 & 100 & 0.045 & 1 \\
\hline Acidic treatment $(\mathrm{pH} 3)$ & 123 & 205.5 & 49 & 0.6 & 13.33 \\
\hline $\begin{array}{c}\left(\mathrm{NH}_{4}\right)_{2} \mathrm{SO}_{4} \\
\text { Precipitation } \\
(60 \%)\end{array}$ & 108 & 108 & 43 & 1 & 22.22 \\
\hline Sephadex G-50 & 95 & 6.41 & 38 & 14.8 & 328.88 \\
\hline MonoS Sepharose & 25 & 0.156 & 10 & 160 & 3555 \\
\hline
\end{tabular}

a) 1 Unit: $\mu$ mole of fatty acid released per min using egg yolk as substrate in the presence of $10 \mathrm{mM} \mathrm{NaTDC}$ and in the presence of $10 \mathrm{mM} \mathrm{CaCl}_{2}$.

b) Proteins were estimated by Bradford method [30]. The experiments were conducted in triplicate.

\section{Enzymatic properties of the purified $\mathrm{ChPLA}_{2}-\mathrm{IIA}$ $\mathrm{Ca}^{2+}$ dependence}

It is well established that $\mathrm{Ca}^{2+}$ is essential for both, catalysis and enzyme binding to the substrate [40-42]. In order to investigate the effect of $\mathrm{Ca}^{2+}$ on $\mathrm{ChPLA}_{2}$-IIA activity, we studied the variation of hydrolysis rates of egg yolk phospholipids by pure ChPLA $\mathrm{C}_{2}$-IIA in the presence of various $\mathrm{Ca}^{2+}$ concentrations (Figure 3A). Our results showed that no $\mathrm{PLA}_{2}$ activity can be detected in the absence of $\mathrm{Ca}^{2+}$ and in the presence of $10 \mathrm{mM}$ EDTA or EGTA. In the absence of calcium chelators, the specific activity of purified $\mathrm{ChPLA}_{2}$ increases to reach $160{\mathrm{U} . \mathrm{mg}^{-1}}^{-1} 10 \mathrm{mM} \mathrm{CaCl}_{2}$ (Figure 3A).

These observations corroborate previous findings with porcine [20], rat [19], and human [14] intestinal $\mathrm{PLA}_{2}$. We previously reported that pancreatic chicken $\mathrm{PLA}_{2}$-IB requires only $4 \mathrm{mM}$ of $\mathrm{CaCl}_{2}$ to reach its maximal activity (Figure 3A and [38]).

\section{Bile salts dependence}

Several studies have provided evidence that bile salts are tensioactive agents ensuring in their micellar form, the dispersion of the lipolytic products (of hydrolysis,) $[43,44]$. Along the same line, De Haas et al. reported that micellar forms of the substrate were hydrolysed at a much higher rate than substrates molecularly dispersed by $\mathrm{PLA}_{2}$ [45]. In this study, we measured the $\mathrm{ChPLA}_{2}$-IIA activity at $\mathrm{pH} 9.0$ and at $40^{\circ} \mathrm{C}$ using egg yolk as substrate in the presence of increasing concentrations of bile salts. As shown in Figure 3B, NaTDC was required for $\mathrm{ChPLA}_{2}$-IIA activity. ChPLA 2 -IIA was poorly active at concentrations lower than $2 \mathrm{mM}$ of NaTDC. This activity increases with increasing bile salts concentration and the maximal $\mathrm{PLA}_{2}$ activity was measured in the presence of $10 \mathrm{mM}$ NaTDC. In contrast, we have presently shown, confirming our previous work, that pancreatic chicken $\mathrm{PLA}_{2}$-IB was found to be active in the absence of NaTDC and its optimal activity was found to be nearly independent of NATDC (Figure 3B and [38]. One has to recall that in the assay using egg yolk emulsion as substrate, the pancreatic $\mathrm{PLA}_{2}$ hydrolyses both $\mathrm{PC}$ and $\mathrm{PE}$ whereas the intestinal enzyme hydrolyses only $\mathrm{PE}$.

\section{Effect of temperature on ChPLA $A_{2}$ IIA activity and stability}

Figure $4 \mathrm{~A}$ shows that the maximal activity of $\mathrm{ChPLA}_{2}-$ IIA was measured at $40^{\circ} \mathrm{C}$ using egg yolk as substrate in the presence of $10 \mathrm{mM} \mathrm{Ca}^{2+}$ and $10 \mathrm{mM} \mathrm{NaTDC}$. Unlike pancreatic ChPLA $\mathrm{C}_{2}$-IB [38] which is totally inactivated at high temperature, the ChPLA $\mathrm{A}_{2}$-IIA maintained about $60 \%$ of its activity after $15 \mathrm{~min}$ of incubation at $60^{\circ} \mathrm{C}$ (Figure $4 \mathrm{~B}$ ). Comparable results were obtained with mammalian intestinal $\mathrm{PLA}_{2}$ from various species which show a good stability at high temperature [46,47].

Effects of $\mathrm{pH}$ on ChPLA $\mathrm{A}_{2}$-IIA activity and stability

As shown in Figure $4 \mathrm{C}$, the maximal activity of $\mathrm{ChPLA}_{2}$-IIA was measured at $\mathrm{pH} 9.0$ and at $40^{\circ} \mathrm{C}$ using egg yolk as substrate in the presence of $10 \mathrm{mM} \mathrm{Ca}^{2+}$ and $10 \mathrm{mM}$ NaTDC. Similar results were obtained with $\mathrm{ChPLA}_{2}$-IB and human intestinal PLA $\mathrm{P}_{2}$-IIA. However, the purified ChPLA $\mathrm{C}_{2}$-IIA was found to be stable between pH 3.0 and 10.0 (Figure 4D). In contrast to the ChPLA ${ }_{2}$ $\mathrm{IB}$, which was found to lose its activity when incubated at $\mathrm{pH}$ lower than 5 [38], pure ChPLA $\mathrm{C}_{2}$-IIA maintained about $50 \%$ of its activity after $15 \mathrm{~min}$ of incubation at pH 3.0 (see Figure 4D). It was also reported that porcine [20] rat [19] and human [14] intestinal $\mathrm{PLA}_{2}$ are stable at low $\mathrm{pH}$ values as compared to ChPLA $\mathrm{C}_{2}$-IIA. Whereas, some pancreatic PLA2-IB are very acid and thermo stable $[37,48]$.

\section{$\mathrm{N}$-terminal sequence of $\mathrm{ChPLA}$-IIA}

The NH2 terminal sequencing of the $\mathrm{ChPLA}_{2}$-IIA allowed unambiguously the identification of the first fourteen residues of pure enzyme. Table 2 shows that the $\mathrm{N}$-terminal sequence of $\mathrm{ChPLA}_{2}$-IIA has identity at $80 \%$ with mouse, $53 \%$ with human, and $53 \%$ with porcine PLA2-IIA respectively. Pure ChPLA2-IIA exhibits a high degree of homology with mouse intestinal PLA $\mathrm{PL}_{2}$-IIA.

\section{Cloning and sequencing of the gene coding ChPLA $\mathrm{A}_{2}-\mathrm{IIA}$} The cDNA encoding ChPLA ${ }_{2}$-IIA was selectively amplified by RT-PCR from total mRNA extracted from 

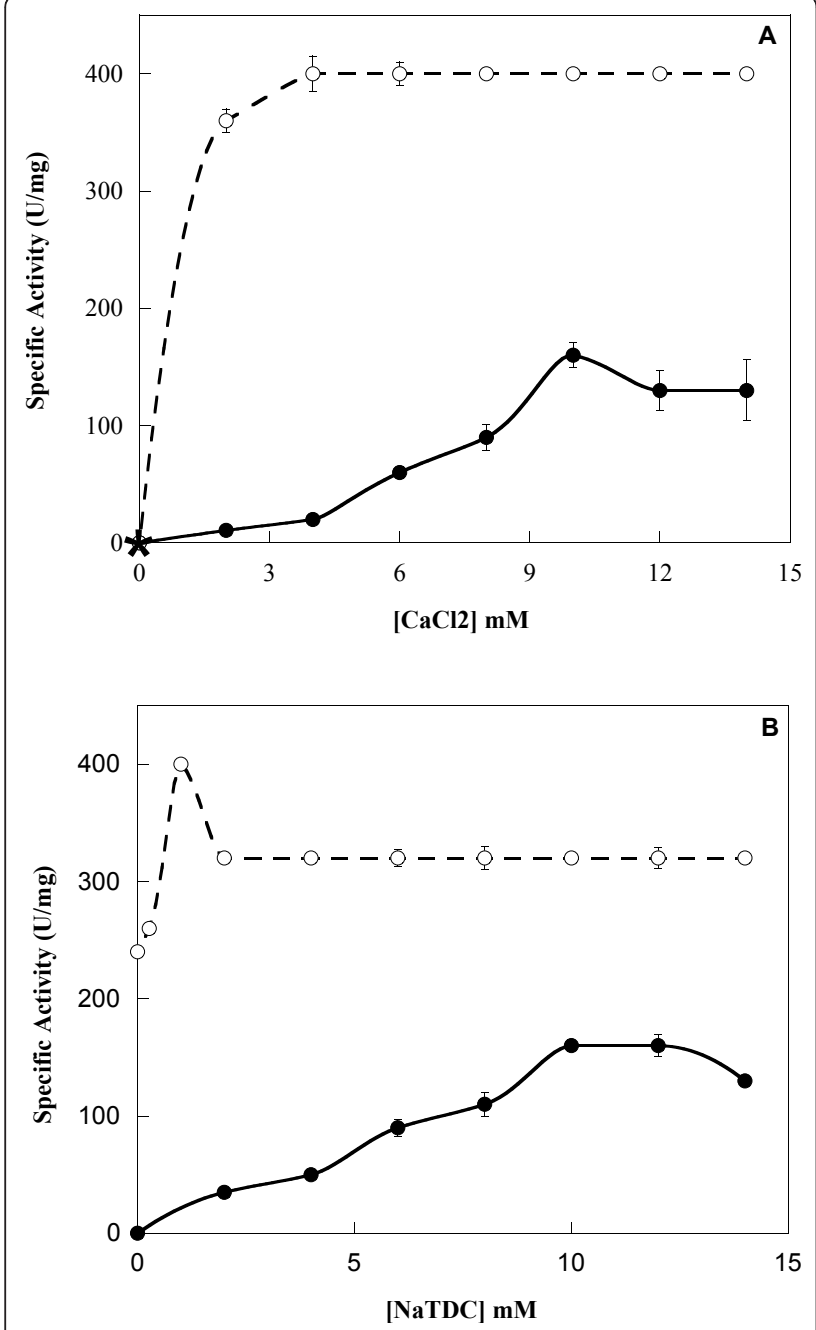

Figure 3 Effect of $\mathrm{Ca}^{2+}$ and NaTDC on ChPLA2-IB and ChPLA2IIA activities. (A) Effect of $\mathrm{Ca}^{2+}$ concentration on ChPLA ${ }_{2}-$ IIA (black circle) and $\mathrm{ChPLA}_{2}-\mathrm{IB}$ (white circle) activities. Enzyme activity was measured at various concentrations of $\mathrm{Ca}^{2+}$ using egg yolk emulsion as substrate at $\mathrm{pH} 9.0$ and at $40^{\circ} \mathrm{C}$ in the presence of 10 $\mathrm{mM}$ NaTDC. The star indicates the phospholipase activity measured in the absence of $\mathrm{CaCl}_{2}$ and in the presence of $10 \mathrm{mM}$ EDTA or EGTA. (B) Effect of increasing concentration of bile salts (NaTDC) on $\mathrm{ChPLA}_{2}-\mathrm{IIA}$ (black circle) and ChPLA $\mathrm{A}_{2}-\mathrm{IB}$ (white circle) activities. PLA activity was measured using egg yolk emulsion as substrate at $\mathrm{pH}$ 9.0 and at $40^{\circ} \mathrm{C}$ in the presence of $10 \mathrm{mM} \mathrm{Ca}^{2+}$.

chicken intestine as described in material and methods. The corresponding DNA was ligated into pET $21 \mathrm{a}(+)$ vector and used for transformation into E. coli $\mathrm{DH} 10 \mathrm{~B}$ cells. Several clones are selected and some of them contained a recombinant plasmid with a $500 \mathrm{pb}$ EcoRI/XhoI insert. The cDNA sequencing, confirmed that the PCR product corresponds to the gene encoding for the mature $\mathrm{ChPLA}_{2}$-IIA (Figure 5). The deduced polypeptide sequence of ChPLA ${ }_{2}$-IIA, corresponding to the mature protein, comprises 123 amino acids. ChPLA $A_{2}$-IIA shares
$45 \%$ of identity with human PLA PIA and $_{2}$-I\% of identity with mouse PLA $\mathrm{A}_{2}$-IIA. Residues of the catalytic diad are conserved in ChPLA $\mathrm{A}_{2}$-IIA. The 14 cystein residues involved in disulfide bridges in all known $\mathrm{PLA}_{2}$ IIA are also conserved in ChPLA2-IIA suggesting also the presence of 7 disulfide bridges in its 3D structure.

\section{Homology modelling}

To provide an insight into the biochemical properties, the structure model of the ChPLA ${ }_{2}$-IIA was built, using the $3 \mathrm{D}$ structure of the hPLA 2 (PDB code: $1 \mathrm{~N} 28$ ) as template. These two proteins shares $45 \%$ amino acid identity. The model of the ChPLA ${ }_{2}$-IIA was then subjected to molecular mechanics optimization using CHARMM27 force-field. Energy minimization (geometry optimization) was performed until the gradient of $0.01 \mathrm{kcal} /(\AA . \mathrm{mol})$ was reached. The RMS deviations involving $\alpha$-carbons between the initial and the optimized models was $0.95 \AA$. The Ramachandran plot

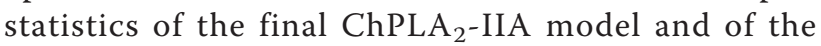
$\mathrm{hPLA}_{2}$, determined using the PROCHECK program, showed that $97.2 \%$, and $100 \%$ of the residues were either in the most favored or in the additional allowed regions, respectively.

\section{Overall 3D structure model of $\mathrm{ChPLA}_{2}$}

As shown in Figure 6, the ChPLA ${ }_{2}$-IIA has a globular shape with an $\alpha / \beta$ hydrolase fold stabilized by seven disulfide bridges similar to those present in all group IIA sPLA2. The core structure consists of four $\alpha$-helices ( $\alpha$ A: Ile2-Thr13; $\alpha$ B: Ala17-Gly22, $\alpha$ C: Ala38-Ser55 and $\alpha D$ : Ser81-Thr103) and two short anti-parallel $\beta$-strands ( $\beta 1$ : Phe67-Lys70 and $\beta 2$ : Gln73-Cys76) located between helix $\alpha \mathrm{C}$ and $\alpha \mathrm{D}$. The catalytic $\mathrm{Ca}^{2+}$ ion is coordinated via oxygen atoms of His 26 and Gly28 which belong to the $\mathrm{Ca}^{2+}$-binding loop and the two oxygen atoms, $\mathrm{O} \delta 1$ and $\mathrm{O} \delta 2$ of Asp47. The ChPLA 2 -IIA model showed that (O) Gly22, (O) Gly24, (O) Tyr111 and (O $\delta 1)$ Asn113 are located at an interaction distance of $2.2 \AA$ with a second $\mathrm{Ca}^{2+}$ ion. However these residues correspond in ChPLA 2 -IB to Asp24, Gly26, Leu118 and Lys120, respectively. No fourth amino acid was found in a favorable position to interact with this ion in $\mathrm{ChPLA}_{2}$ IB due to the substitution of Asn113 (O $\delta 1)$ (in $\mathrm{ChPLA}_{2}$ IIA) by Lys120 (in ChPLA 2 -IB). This second $\mathrm{Ca}^{2+}$ ion may help the stabilization of the C-terminal (Tyr111 and Asn113) with the helix $\alpha \mathrm{B}$ (Gly22, and Gly24) and furthermore the $\mathrm{Ca}^{2+}$-binding loop.

Although ChPLA $A_{2}$-IIA and ChPLA ${ }_{2}$-IB share seven disulfide bridges, only six of them are structurally conserved. In ChPLA $\mathrm{A}_{2}-\mathrm{IB}$, the disulfide bridge between Cys 11 and Cys77 may stabilize the $\mathrm{N}$-terminal $\alpha$-helix $\alpha \mathrm{A}$ with one of the two short strands of an anti-parallel $\beta$-sheet ( $\beta$-wing) ( $\beta 2$ ). However, in ChPLA ${ }_{2}$-IIA, one 

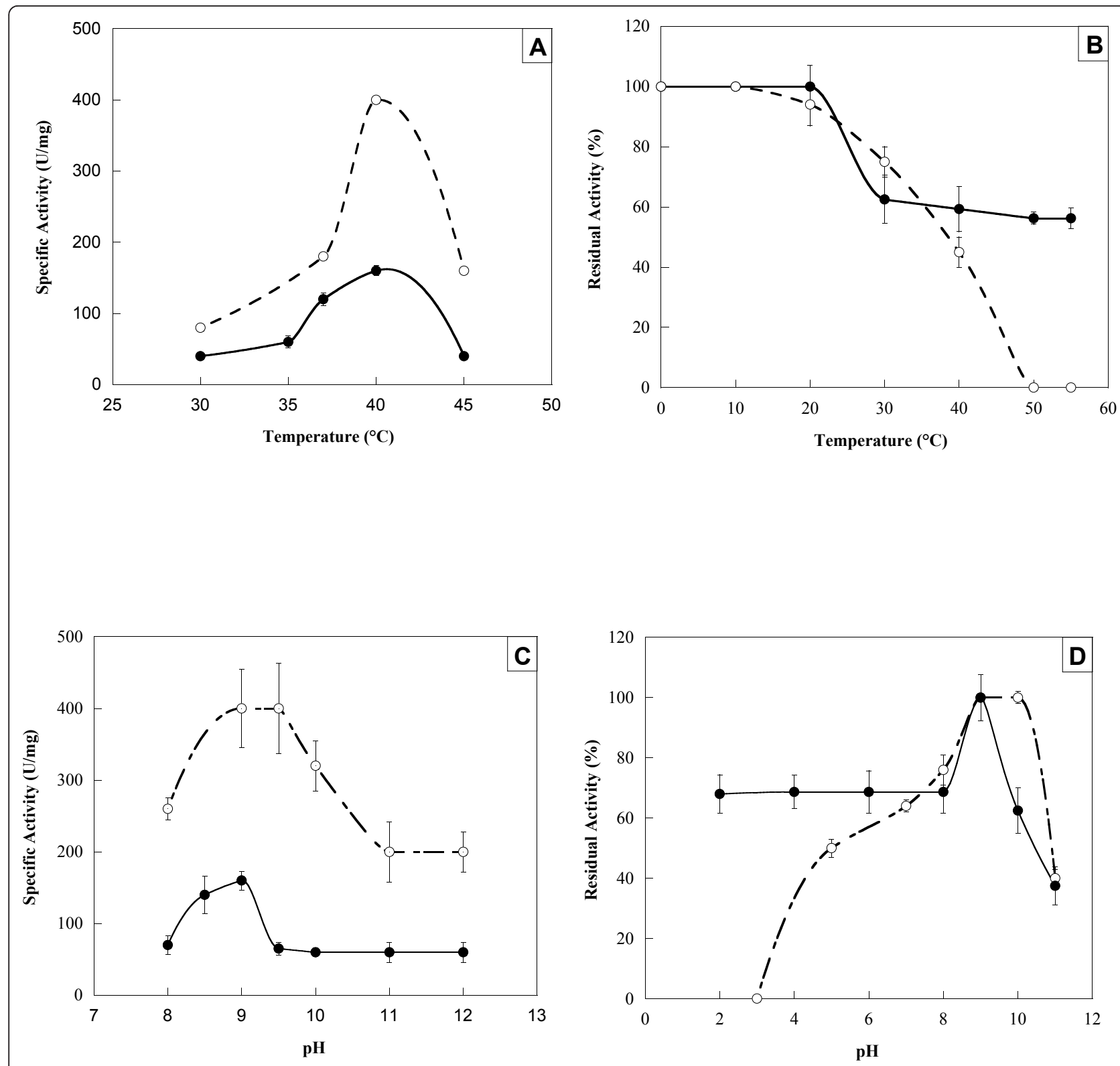

Figure 4 Effect of temperature and pH on ChPLA2-IB and ChPLA2-IIA. Effects of temperature $(\mathbf{A}, \mathbf{B})$ and pH (C, D) on ChPLA circle) and $\mathrm{ChPLA}_{2}-\mathrm{BB}$ (white circle) activities (A, C) and stability (B, D). PLA 2 were tested for activity at various temperatures $(\mathbf{A})$ and $\mathrm{pH}(\mathbf{C})$ as described in material and methods. To study the stability of $\mathrm{PLA}_{2}, 1 \mathrm{mg} \cdot \mathrm{ml}^{-1}$ of each enzyme was incubated during 30 min at various temperatures (B) and pH (D). Residual PLA 2 activity was measured using egg yolk as substrate in the presence of $10 \mathrm{mM} \mathrm{Ca}{ }^{2+}$ and $10 \mathrm{mM}$ NaTDC. For temperature stability studies, enzymes were incubated in $10 \mathrm{mM}$ Tris (pH 8.0) and $10 \mathrm{mM} \mathrm{CaCl}$. For pH stability studies, Tris buffer was replaced by the appropriate buffer for the $\mathrm{pH}$ range.

Table 2 Alignment of the $\mathrm{N}$-terminal amino-acid

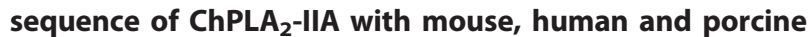
intestinal phospholipases

\begin{tabular}{lll}
\hline Chicken: & N I A Q F G I M I K E K T G K & (present work) \\
\hline Mouse: & N / A Q F G E M I R L K T G K & {$[19]$} \\
\hline Human: & N L V N F H R M I KL T T G K & {$[14]$} \\
\hline Porcine: & D L L N F R K M I K L K T G K & {$[20]$} \\
\hline
\end{tabular}

Identical aminoacids are in bold, and homologous aminoacids are in italic. new disulfide bridge is formed between Cys48 (belong to helix $\alpha C$ ) and C-terminal Cys123.

To get more insight on the stabilization effect of the second calcium ion, molecular dynamics simulations were carried out ( $1 \mathrm{~ns})$ at $330^{\circ} \mathrm{K}$ for the minimized models of the ChPLA $_{2}$-IIA in the presence and the absence of this ion. The RMSD value for the backbone atoms was used to understand the response behavior. The 2D-RMSD plot, 


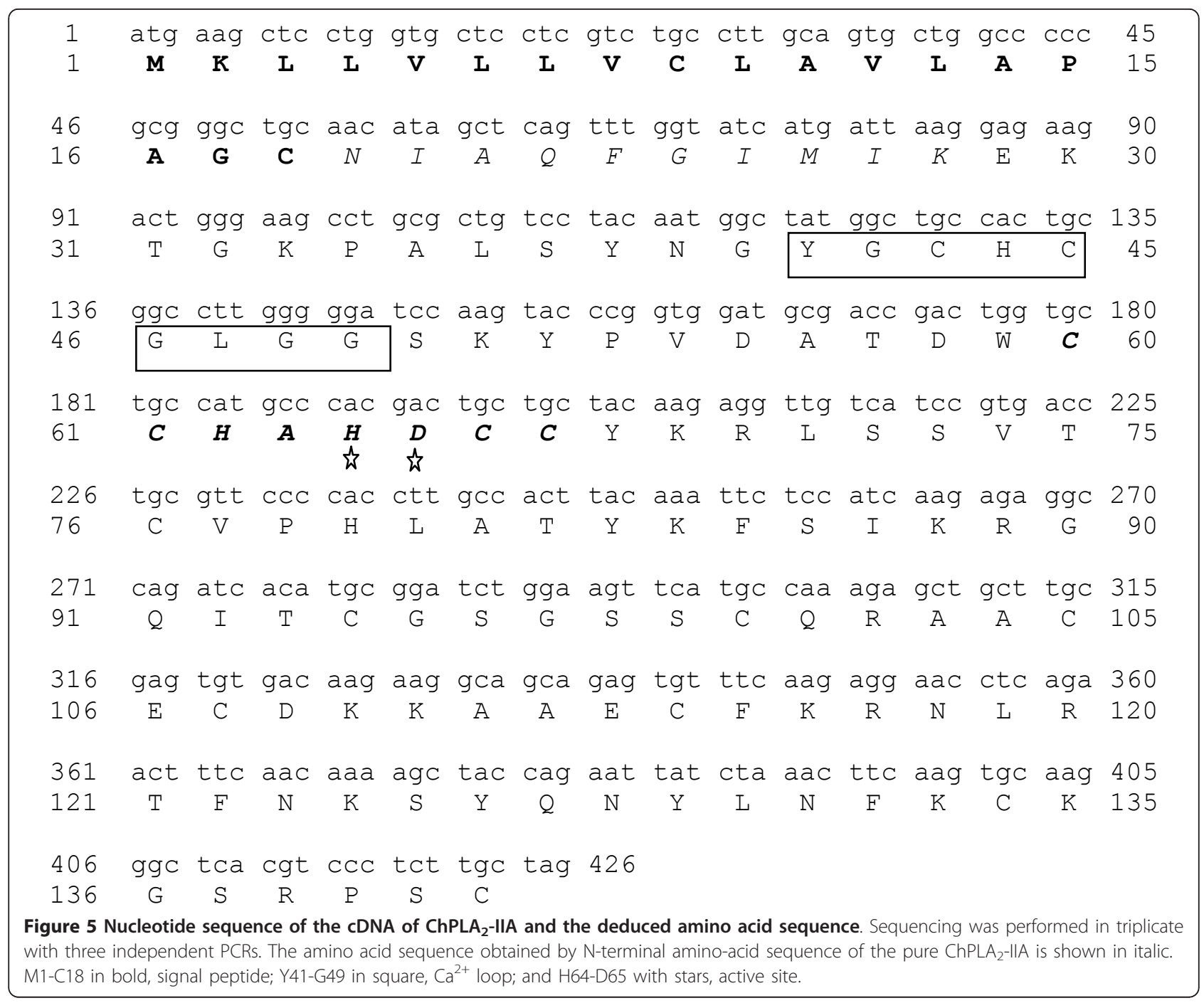

where the root mean square deviation of every conformation to all others of a simulation is shown, demonstrated that the

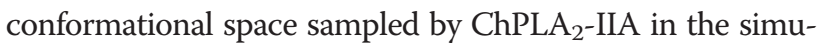
lations was larger in the absence of $\mathrm{Ca}^{2+}$ ion (Figure 6).

\section{Docking}

The total accessible surface area of the ChPLA -IIA and $_{2}$ $\mathrm{ChPLA}_{2}$-IB were 6591 and $6522 \AA^{2}$, respectively. The positive charged surface of the ChPLA ${ }_{2}$-IIA $\left(876 \AA^{2}, 12.6 \%\right)$ was higher than that of ChPLA $\mathrm{C}_{2}$-IB (440 $\left.\AA^{2}, 6.7 \%\right)$. Furthermore, the negative charged surfaces of the $\mathrm{ChPLA}_{2}$-IIA and ChPLA 2 -IB were $69 \AA^{2},(1 \%)$ and $399 \AA^{2}$, (6.1\%), respectively.

Analysis of $\mathrm{PLA}_{2}$ structures bound to a substrate can help in understanding the interaction mode of the substrate once located in the catalytic pocket.

The docking of the substrate (PC, PE or PG) to the $\mathrm{ChPLA}_{2}$-IIA and the ChPLA $\mathrm{C}_{2}$-IB protein was performed using the Molegro Virtual Docker v.4.0.2 software, respectively (data not shown). According to the proteinsubstrate complexes, 13 or 12 residues are in van der vaals contact with the substrate in the case the ChPLA 2 -IIA and $\mathrm{ChPLA}_{2}$-IB, respectively. In the case of the ChPLA $\mathrm{CHA}_{2}$-IIA the total interaction energy between the protein and the target substrate is $-134.8,-128.4$ and $-137,9 \mathrm{~kJ} / \mathrm{mol}$ for $\mathrm{PC}$, PE or PG respectively. In the case of the ChPLA $\mathrm{C}_{2}-\mathrm{IB}$, the total interaction energy is $-183.8,-142.3$ and $-192.2 \mathrm{~kJ} / \mathrm{mol}$ for PC, PE or PG respectively. These above mentioned interaction energy may help to explain the lack of catalytic

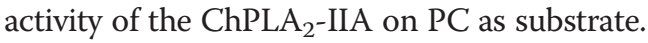

\section{Materials and methods}

\section{Materials}

Benzamidine was from Fluka (Buchs, Switzerland), bovine serum albumine (BSA), anhydrous magnesium sulfate, anhydrous sodium sulfate, potassium chloride, sodium chloride, taurodeoxycholic acid sodium salt (NaTDC) and PC were purchased from Sigma Chemical 


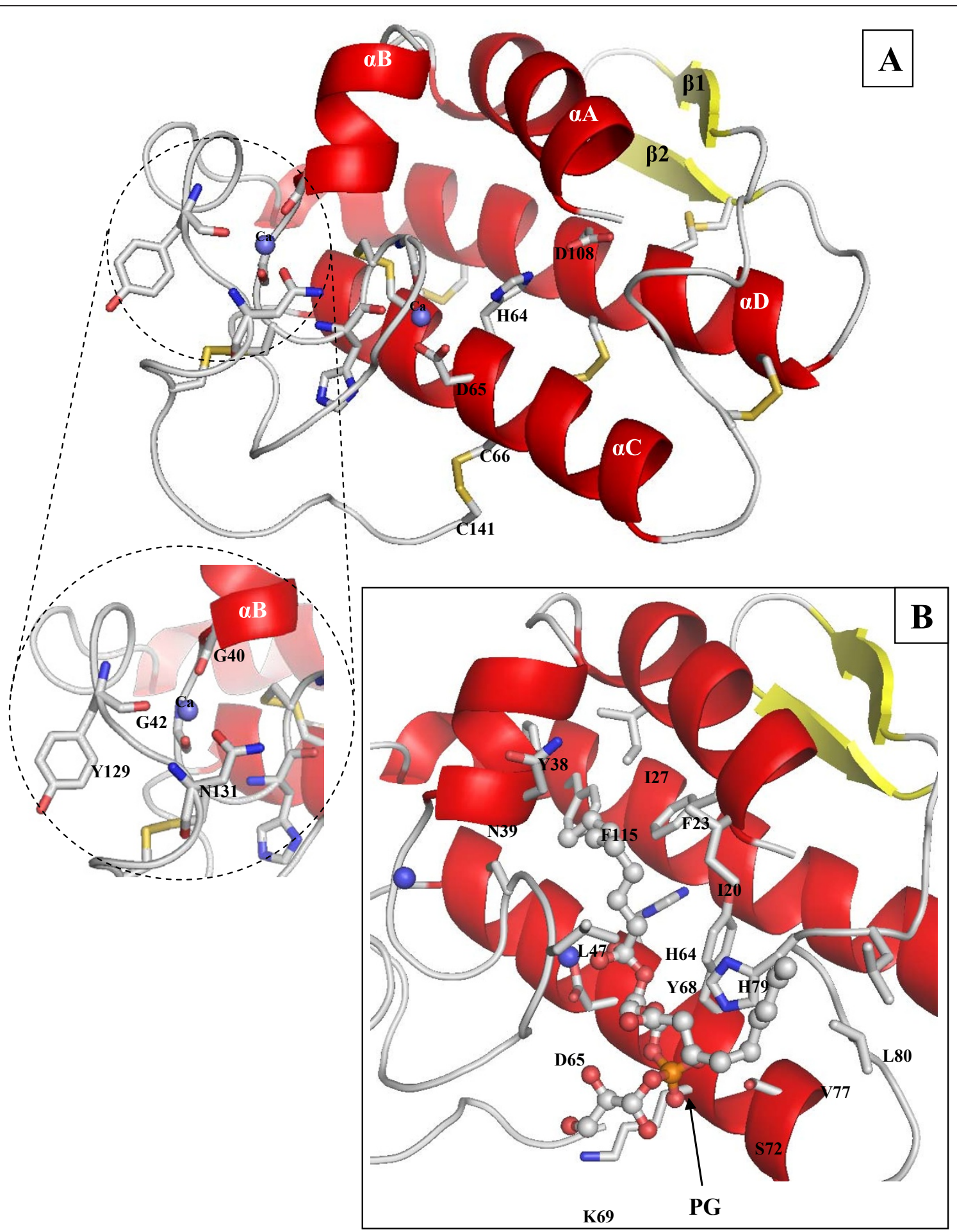

Figure 6 3D modelling structure of ChPLA2-IIA. (A) Cartoon representation the 3D model of the mature ChPLA - IIA. Secondary structure elements labels are indicated. $\alpha$-helices and $\beta$-strands are colored in red and yellow, respectively. The catalytic network and the $\mathrm{Ca}^{2+}$-binding residues are indicated and shown as sticks. The disulfide-bridges are shown in yellow. (B) Cartoon representation of the ChPLA $-\|$ A structure showing amino acids (represented by sticks) interacting with the substrate (PG). The substrate is indicated as a stick representation. The $\mathrm{Ca}^{2+}$ ions are represented by a blue spheres. This figure was generated using the PYMOL software. 
(St. Louis, MO, USA); acrylamide and bis-acrylamide electrophoresis grade were from BDH (Poole, UK), marker proteins and supports of chromatography used for phospholipase purification: Sephadex G-50, MonoS sepharose, were from Pharmacia (Uppsala, Sweden); protein sequencer Procise 492 equipped with $140 \mathrm{C}$ HPLC system provided from Applied Biosystems (Roissy, France); pH-stat was from Metrohm (Herisau, Switzerland).

All enzymes and reagents used in DNA manipulations were from Promega and Invitrogen (Paris, France). Oligonuclotides were synthesized by Invitrogen. E. coli strain DH10B was used as cloning host for the gene part encoding the mature phospholipase. PCR products were purified using the Wizard PCR Preps DNA purification System (Promega).

Thin-layer Silica Gel 60 plates $(10 \times 20 \mathrm{~cm}$ from Merck) were used for the separation of lipids. Lipid standards ( $\alpha$-L-oleic acid C 18:1) and silica gel 60 powders (70-230) were from Sigma-Aldrich (Steinheim, Germany). All solvents with HPLC grade were purchased from SDS (Peypin, France).

\section{Lipid extraction, separation and analysis}

Ten micrograms of purified ChPLA $\mathrm{C}_{2}$-IB and purified $\mathrm{ChPLA}_{2}$-IIA were incubated respectively with $25 \mu \mathrm{M}$ of pure phosphatidylcholine (PC) and phosphatidylethanol (PE) dispersion in $1 \mathrm{ml}$ buffer $(10 \mathrm{mM}$ Tris $\mathrm{HCl}, 10 \mathrm{mM}$ $\mathrm{NaTDC}$ and $10 \mathrm{mM} \mathrm{CaCl} 2$ ) at $37^{\circ} \mathrm{C}$ for 10 minutes. Lipolysis was stopped by adding $200 \mu \mathrm{l}$ of $1 \mathrm{M} \mathrm{HCL}$ and mixing vigorously with $5 \mathrm{ml}$ of chloroform/methanol mixture $(2: 1, \mathrm{v} / \mathrm{v})$ in a $15 \mathrm{ml}$ glass tube with a Teflon-lined screw cap. Lipids were immediately extracted as follows: after separation phases, the lower organic phase was transferred to a $15-\mathrm{ml}$ test tube and dried over anhydrous magnesium sulphate. Once $\mathrm{MgSO}_{4}$ had precipitated, the clear organic phase was removed by centrifugation and stored at $-20^{\circ} \mathrm{C}$ before TLC analysis.

To separate lipid classes, 1 to $50 \mu$ l of lipid extracts or lipid standards at known concentrations were first spotted onto a thin-layer silica plate. The elution of the lipids was then performed in one step with a chloroform/methanol/water $(65 / 25 / 4, \mathrm{v} / \mathrm{v} / \mathrm{v})$ solvent mixture. Following chromatography, the plates were dried at room temperature for $10 \mathrm{~min}$ then immediately placed in the iodine.

\section{Enzyme samples}

The intestine from chicken was collected from a local slaughterhouse (Sfax, Tunisia). Immediately after slaughter, the most distal intestine was opened on a glass plate on ice. The content of each ileal segment was flushed twice with $100 \mathrm{ml}$ of $0.15 \mathrm{M} \mathrm{NaCl}$. Adherent mesentery was removed as completely as possible.

\section{Purification of ChPLA $\mathrm{Al}_{2}$ IIA}

Fifty grams of chicken intestine mucosa were suspended in $50 \mathrm{ml}$ of buffer $\mathrm{A}(0.01 \mathrm{M}$ Tris- $\mathrm{HCl} \mathrm{pH} \mathrm{8,0.15} \mathrm{M}$ $\mathrm{NaCl}, 0.02 \mathrm{M} \mathrm{CaCl}_{2}$ and $4 \mathrm{mM}$ Benzamidine), and ground mechanically twice for $30 \mathrm{~s}$ at room temperature using the Waring Blendor system. Then, the mixture was stirred in a cold room for $1 \mathrm{~h}$ and centrifuged during $30 \mathrm{~min}$ at $12.000 \mathrm{rpm}$. The total $\mathrm{PLA}_{2}$ intestine activity obtained was $250 \mathrm{U}$.

\section{Acidic treatment}

To inactivate proteins from the pancreatic juice and secreted into the intestine, the supernatant was brought to $\mathrm{pH} 3.0$ by adding $6 \mathrm{~N} \mathrm{HCl}$ under gentle stirring at $0^{\circ} \mathrm{C}$. Insoluble denatured proteins were removed by centrifugation during $30 \mathrm{~min}$ at $12.000 \mathrm{~g}$ and the clear supernatant was adjusted to $\mathrm{pH} 8.0$ with $4 \mathrm{~N} \mathrm{NaOH}$. The recovery of $\mathrm{PLA}_{2}$ activity was of about $50 \%$.

\section{Ammonium sulphate precipitation}

The supernatant (55 ml, $123 \mathrm{U}$ ) was brought to $60 \%$ saturation with solid ammonium sulphate under stirring conditions and maintained during $45 \mathrm{~min}$ at $4^{\circ} \mathrm{C}$. After centrifugation for $30 \mathrm{~min}$ at $12.000 \mathrm{~g}$ and at $4^{\circ} \mathrm{C}$, the precipitated $\mathrm{PLA}_{2}$ was resuspended in $2 \mathrm{ml}$ of buffer $\mathrm{A}$ containing $2 \mathrm{mM}$ benzamidine. Insoluble material was removed by centrifugation for $10 \mathrm{~min}$ at $24.000 \mathrm{~g}$. The recovery of $\mathrm{PLA}_{2}$ activity was about $45 \%$.

\section{Filtration on Sephadex G-50}

The sample containing $\mathrm{PLA}_{2}$ activity $(4 \mathrm{ml}, 108 \mathrm{U})$ was loaded on a column of sephadex G-50 $(34 \mathrm{~cm} \times 1.5 \mathrm{~cm})$ equilibrated with buffer $\mathrm{B}(20 \mathrm{mM}$ Tris- $\mathrm{HCl}, \mathrm{pH} 8$ and $20 \mathrm{mM} \mathrm{CaCl}_{2}$ ). Elution of proteins was performed with the same buffer at $40 \mathrm{ml} \cdot \mathrm{h}^{-1}$. The fractions containing the $\mathrm{PLA}_{2}$ activity eluted between 1.5 and 1.8 void volumes were pooled (Figure 2A).

\section{Cation exchange chromatography}

The pooled fractions of Sephadex G-50 column containing $\mathrm{PLA}_{2}$ activity were poured into a Mono-S column $(5 \mathrm{~cm} \times$ $2 \mathrm{~cm}$ ) equilibrated with buffer $\mathrm{B}$. Under these conditions, the enzyme is adsorbed to the anionic support and the column was washed with $60 \mathrm{ml}$ of the same buffer containing $0.3 \mathrm{M} \mathrm{NaCl}$. ChPLA $\mathrm{A}_{2}$-IIA was eluted by a linear salt gradient (0.3-1 M) NaCl as shown in Figure 2B.

\section{Analytical methods}

Protein concentration was determined as described by Bradford et al. [49] using BSA $(\underset{1 \mathrm{~cm}}{\mathrm{E}}=6.7)$ as reference.

Analytical polyacrylamide gel electrophoresis of proteins in the presence of sodium dodecyl sulfate 
(SDS-PAGE) was performed by the method of Laemmli [50]. The proteins were stained with Coomassie brilliant blue.

\section{Amino acid sequencing}

The N-terminal sequence was determined by automated Edman's degradation, using an Applied Biosystems Protein Sequencer Procise 492 equipped with 140C HPLC system.

\section{Bacterial starins, plasmids and media}

E. coli strain DH10B was used as cloning host for the gene part encoding for the mature $\mathrm{PLA}_{2}$. E. coli strain was grown in Luria-Bertani medium, supplemented with $100 \mu \mathrm{g} \cdot \mathrm{ml}^{-1}$ ampicilline whenever plasmid maintenance was required. The plasmid pET21a $(+)$ (Novagen) was used as cloning vector.

\section{cDNA synthesis and amplification}

Total mRNAs were isolated from chicken intestine using the single step guanidine isothiocyanate/phenol/chloroform isolation method as described by Chomczynski and

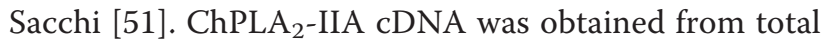
mRNAs by the reverse transcription procedure (Promega). First strand cDNAs were prepared using $10 \mu \mathrm{g}$ of total mRNAs as template (heat-denaturated for $5 \mathrm{~min}$ at $70^{\circ} \mathrm{C}$,) $200 \mathrm{U}$ MMLV reverse transcriptase (Invitrogen), 20 pmol of each deoxynucleoside triphosphate, and 20 pmol of each primer: forward primer, 5'- GAA TTC ATG AAG CTC C TG GTG CTC CT C -3' and reverse primer, 5'- CT C GAG CTA GCA AGA GGG ACG TGA GCC -3'. The N-terminal primer was predicted, from the $\mathrm{N}$-terminal sequence of the ChPLA $\mathrm{P}_{2}$, however the $\mathrm{C}$-terminal primer was deduced from the genome of Gallus gallus (GenBank accession number: XP 424364). Reverse transcription was carried out in a total reaction volume of $20 \mu \mathrm{l}$ for $5 \mathrm{~min}$ at room temperature and $60 \mathrm{~min}$ at $42^{\circ} \mathrm{C}$. The cDNA/RNA heteroduplex was then denaturated at $70^{\circ} \mathrm{C}$ for $15 \mathrm{~min}$ and cooled on ice.

\section{Cloning of the mature PLA 2 gene}

Amplification of the specific ChPLA AIA $_{2}$-IDNA was carried out by PCR using the single strand cDNAs as template with the forward and reverse primers previously described. PCR was performed in a $0.2 \mathrm{ml}$ Eppendorf tube with a Gene Amp ${ }^{\circledR}$ PCR System 2700. The PCR mixture contained 20 pmol of both primers, 20 pmol of each deoxynucleoside triphosphate, $5 \mathrm{U} \mathrm{pfx}$ polymerase and polymerisation buffer in final volume of $100 \mu \mathrm{l}$. The single strand cDNAs were directly used as template. The thermal profile involved 35 cycles of denaturation at $94^{\circ} \mathrm{C}$ for $1 \mathrm{~min}$, primer annealing at $60^{\circ}$ $\mathrm{C}$ for $1 \mathrm{~min}$, and extension at $72^{\circ} \mathrm{C}$ for $3 \mathrm{~min}$. The PCR product $(500 \mathrm{pb})$ was isolated and ligated into the EcoRI and XhoI linearised and dephosphorylated pET21a(+) vector, according to the manufacturer's protocol (Promega). Protoplasts of E. coli DH10B were transformed with the ligation mixture. The resulting recombinant plasmid was named pChPLA $A_{2}$. The presence of the appropriated insert was verified by restriction analysis. DNA sequences were elucidated by the dideoxynucleotide chain termination method according to a cycle sequencing protocol using thermosequenase (Amersham Pharmacia Biotech). The sequencing reactions were analysed with the DNA sequencer ABI PRISM 3100/ 3100-Avant Genetic Analyser (California, USA). It was performed three times, using the recombinant vector $\mathrm{pChPLA}_{2}$ as template with T7 promoter primer and the T7 reverse primer (Invitrogen).

\section{Software for infrastructure}

The sequence alignment was performed with BioEdit Version 4.8.4 software. The Molecular Operating Environment 2008.10 (MOE) software was used for homology modelling, molecular dynamics and structures visualization. Models were stereochemically evaluated by the program PROCHECK. The Visualization was performed with PyMol version 0.99beta06. Figures were generated by PyMol program.

\section{Homology Modelling}

The 3-D coordinates of the human group IIA secreted $\mathrm{PLA}_{2}\left(\mathrm{hPLA}_{2}\right.$ ) (PDB code: $\left.1 \mathrm{~N} 28\right)$ was extracted from the Protein Data Bank http://www.rcsb.org. The hPLA ${ }_{2}$ structure was used as template to build a model of the $\mathrm{ChPLA}_{2}$-IIA by using the structure-modelling program Molecular Operating Environment 2008.10. The model was then subjected to molecular mechanics optimization using CHARMM27 force field, until a gradient of 0.01 $\mathrm{kcal} /(\AA . \mathrm{mol})$ was reached.

\section{Docking}

The 1,2-dioctylcarbamoylglycero-3-O-phosphatidylcholine (PC), 1,2-dioctylcarbamoylglycero-3-O-phosphatidylethanolamine (PE) and 1,2-dioctylcarbamoylglycero-3-O-phosphatidylglycerol (PG) were modelled by the Molecular Operating Environment 2008.10 (MOE) software using a Simplified Molecular Input Line Entry Specification (SMILES). The Molegro Virtual Docker v.4.0.2 software was used for docking substrates, PC, PE or PG to the $\mathrm{ChPLA}_{2}$-IIA and the ChPLA ${ }_{2}$-IB protein, respectively.

The potential binding sites (also referred to as cavities or active sites) was being identified using the built-in cavity detection algorithm, molecular surface with $0.5 \AA$ grid resolutions and $1.2 \AA$ Probe size.

After preparation of the protein and the ligand, the docking was performed using MolDock Score function, MolDock SE search algorithm, 10 runs, energy minimization and optimize $\mathrm{H}$-Bonds after docking, 2500 
iterations and 500 steps Simplex Evolution to generate the best five poses scores which were visually analyzed. Only one of these poses correctly bind to the active site with a high score was used. The protein-substrate complex was then subjected to molecular mechanics optimization using CHARMM27 force field as described previously. The Score of the final protein-substrate complex was evaluated using the total interaction energy between the active site and the substrate.

\section{Statistical analysis}

All the results in figures and text are the average of at least three replicate experiments. They were statistically analyzed with SPSS software (version 100), using the Duncan test performed after analysis of variance (ANOVA).

\section{Abbreviation}

PLA 2 : phospholipase A2; sPLA 2 secreted PLA $A_{2}$ ChPLA $-I B$ : Group IB chicken pancreatic PLA ChPLA $_{2}-$ IIA : Group IIA chicken intestinal PLA 2 i hPLA 2 -IA: Group IIA human PLA 2 NaTDC: taurodeoxycholic acid sodium salt; PC: phosphtidylcholine; PE: phosphatidylethanolamine; TLC: thin layer chromatography; ns: nanosecond. MMLV: Moloney murine leukemia virus.

\section{Acknowledgements}

This work represents a part of thesis of A. Karray. It was supported by DGRST granted to the "Laboratoire de Biochimie et de Génie Enzymatique des Lipases". The authors highly acknowledge Dr Robert Verger (EIPL-CNRS, Marseille-France) for his fruitful help and discussion during the preparation of this work. Our thanks are due to $\operatorname{Pr} H$. Mejdoub (FSS, Tunisia) for the sequencing of the $\mathrm{NH}_{2}$-terminal of ChPLA2-IIA.

\section{Authors' contributions}

AK carried out all the studies, analyzed the data and drafted the manuscript. FF carried out modelling and structural analysis. YBA helped with the analysis of the data and to correct the manuscript. YG helped with the discussion of the data and the correction of the manuscript. SB participated in the study design and helped to draft the manuscript. All authors have read and approved the final manuscript.

\section{Competing interests}

The authors declare that they have no competing interests.

Received: 11 December 2010 Accepted: 1 February 2011 Published: 1 February 2011

\section{References}

1. Six DA, Dennis EA: The expanding superfamily of phospholipase $A(2)$ enzymes: classification and characterization. Biochim Biophys Acta 2000, 1488(1-2):1-19.

2. Balsinde J, Balboa MA, Insel PA, Dennis EA: Regulation and inhibition of phospholipase A2. Annu Rev Pharmacol Toxicol 1999, 39:175-189.

3. Valentin E, Lambeau G: Increasing molecular diversity of secreted phospholipases $A(2)$ and their receptors and binding proteins. Biochim Biophys Acta 2000, 1488(1-2):59-70.

4. Nevalainen TJ, Haapanen TJ: Distribution of pancreatic (group I) and synovial-type (group II) phospholipases A2 in human tissues. Inflammation 1993, 17(4):453-464

5. Yoshikawa T, Naruse S, Kitagawa M, Ishiguro H, Nakae Y, Ono T, Hayakawa T: Effect of a new inhibitor of type II phospholipase A2 on experimental acute pancreatitis in rats. Pancreas 1999, 19(2):193-198.

6. Pfeilschifter J, Schalkwijk C, Briner VA, van den Bosch H: Cytokinestimulated secretion of group II phospholipase A2 by rat mesangial cells. Its contribution to arachidonic acid release and prostaglandin synthesis by cultured rat glomerular cells. J Clin Invest 1993, 92(5):2516-2523.

7. Hurt-Camejo E, Camejo G, Peilot H, Oorni K, Kovanen P: Phospholipase A (2) in vascular disease. Circ Res 2001, 89(4):298-304.

8. Bidgood MJ, Jamal OS, Cunningham AM, Brooks PM, Scott KF: Type IIA secretory phospholipase A2 up-regulates cyclooxygenase-2 and amplifies cytokine-mediated prostaglandin production in human rheumatoid synoviocytes. J Immunol 2000, 165(5):2790-2797.

9. Menschikowski M, Hagelgans A, Siegert G: Secretory phospholipase A2 of group IIA: is it an offensive or a defensive player during atherosclerosis and other inflammatory diseases? Prostaglandins Other Lipid Mediat 2006, 79(1-2):1-33

10. Rosenson RS, Gelb MH: Secretory phospholipase A2: a multifaceted family of proatherogenic enzymes. Curr Cardiol Rep 2009, 11(6):445-451.

11. Sullivan $C P$, Seidl $S E$, Rich $C B$, Raymondjean M, Schreiber BM: Secretory phospholipase A2, group IIA is a novel serum amyloid A target gene: activation of smooth muscle cell expression by an interleukin-1 receptor-independent mechanism. J Biol Chem 2010, 285(1):565-575.

12. Seilhamer JJ, Randall TL, Yamanaka M, Johnson LK: Pancreatic phospholipase A2: isolation of the human gene and CDNAs from porcine pancreas and human lung. DNA 1986, 5(6):519-527.

13. Seilhamer JJ, Pruzanski W, Vadas P, Plant S, Miller JA, Kloss J, Johnson LK: Cloning and recombinant expression of phospholipase A2 present in rheumatoid arthritic synovial fluid. J Biol Chem 1989, 5(10):5335-5338.

14. Kramer RM, Hession C, Johansen B, Hayes G, McGray P, Chow EP, Tizard R, Pepinsky RB: Structure and properties of a human non-pancreatic phospholipase A2. J Biol Chem 1989, 264(10):5768-5775.

15. Rouault M, Bollinger JG, Lazdunski M, Gelb MH, Lambeau G: Novel mammalian group XII secreted phospholipase A2 lacking enzymatic activity. Biochemistry 2003, 42(39):11494-11503.

16. Schaloske RH, Dennis EA: The phospholipase A2 superfamily and its group numbering system. Biochim Biophys Acta 2006, 1761(11):1246-1259.

17. Bezzine S, Koduri RS, Valentin E, Murakami M, Kudo I, Ghomashchi F, Sadilek M, Lambeau G, Gelb MH: Exogenously added human group X secreted phospholipase $A(2)$ but not the group IB, IIA, and V enzymes efficiently release arachidonic acid from adherent mammalian cells. J Biol Chem 2000, 275(5):3179-3191.

18. Singer AG, Ghomashchi F, Le Calvez C, Bollinger J, Bezzine S, Rouault M, Sadilek M, Nguyen E, Lazdunski M, Lambeau G, et al: Interfacial kinetic and binding properties of the complete set of human and mouse groups I, II, V, X, and XII secreted phospholipases A2. J Biol Chem 2002, 277(50):48535-48549.

19. Mansbach CM, Pieroni $G$, Verger R: Intestinal phospholipase, a novel enzyme. J Clin Invest 1982, 69(2):368-376.

20. Verger R, Ferrato F, Mansbach CM, Pieroni G: Novel intestinal phospholipase A2: purification and some molecular characteristics. Biochemistry 1982, 21(26):6883-6889.

21. Pruzanski W, Vadas P, Stefanski E, Urowitz MB: Phospholipase A2 activity in sera and synovial fluids in rheumatoid arthritis and osteoarthritis. Its possible role as a proinflammatory enzyme. J Rheumatol 1985, 12(2):211-216.

22. Crowl RM, Stoller TJ, Conroy RR, Stoner CR: Induction of phospholipase A2 gene expression in human hepatoma cells by mediators of the acute phase response. J Biol Chem 1991, 266(4):2647-2651.

23. Nevalainen TJ: Serum phospholipases A2 in inflammatory diseases. Clin Chem 1993, 39(12):2453-2459.

24. Nevalainen TJ, Hietaranta AJ, Gronroos JM: Phospholipase A2 in acute pancreatitis: new biochemical and pathological aspects. Hepatogastroenterology 1999, 46(29):2731-2735

25. Senegas-Balas F, Balas D, Verger R, de Caro A, Figarella C, Ferrato F, Lechene P, Bertrand C, Ribet A: Immunohistochemical localization of intestinal phospholipase A2 in rat paneth cells. Histochemistry 1984, 81(6):581-584

26. Qu XD, Lloyd KC, Walsh JH, Lehrer Rl: Secretion of type II phospholipase A2 and cryptdin by rat small intestinal Paneth cells. Infect Immun 1996, 64(12):5161-5165.

27. Murakami M, Nakatani $Y$, Atsumi G, Inoue $K$, Kudo I: Regulatory functions of phospholipase A2. Crit Rev Immunol 1997, 17(3-4):225-283. 
28. Balsinde J, Dennis EA: Distinct roles in signal transduction for each of the phospholipase A2 enzymes present in P388D1 macrophages. J Biol Chem 1996, 271(12):6758-6765.

29. Weinrauch Y, Abad C, Liang NS, Lowry SF, Weiss J: Mobilization of potent plasma bactericidal activity during systemic bacterial challenge. Role of group IIA phospholipase A2. J Clin Invest 1998, 102(3):633-638.

30. Gronroos JO, Salonen JH, Viander M, Nevalainen TJ, Laine VJ: Roles of group IIA phospholipase A2 and complement in killing of bacteria by acute phase serum. Scand J Immunol 2005, 62(4):413-419.

31. Harwig SS, Tan L, Qu XD, Cho Y, Eisenhauer PB, Lehrer Rl: Bactericidal properties of murine intestinal phospholipase A2. J Clin Invest 1995, 95(2):603-610.

32. Nevalainen TJ, Graham GG, Scott KF: Antibacterial actions of secreted phospholipases A2. Review. Biochim Biophys Acta 2008, 1781(1-2):1-9.

33. Koduri RS, Gronroos JO, Laine VJ, Le Calvez C, Lambeau G, Nevalainen TJ, Gelb MH: Bactericidal properties of human and murine groups I, II, V, X, and XII secreted phospholipases A(2). J Biol Chem 2002, 277(8):5849-5857.

34. Birts $\mathrm{CN}$, Barton $\mathrm{CH}$, Wilton DC: Catalytic and non-catalytic functions of human IIA phospholipase A2. Trends Biochem Sci 2010, 35(1):28-35.

35. Marth T: New insights into Whipple's disease - a rare intestinal inflammatory disorder. Digestive Diseases 2009, 27(4):494-501.

36. Bezzine $S$, Bollinger JG, Singer $A G$, Veatch $S L$, Keller SL, Gelb MH: On the binding preference of human groups IIA and $\mathrm{X}$ phospholipases $\mathrm{A} 2$ for membranes with anionic phospholipids. J Biol Chem 2002, 277(50):48523-48534.

37. Ben Bacha A, Gargouri Y, Bezzine S, Mosbah H, Mejdoub H: Ostrich pancreatic phospholipase $A(2)$ : Purification and biochemical characterization. J Chromatogr B Analyt Technol Biomed Life Sci 2007, 857(1):108-114.

38. Karray A, Frikha F, Ben Bacha A, Ben Ali Y, Gargouri Y, Bezzine S: Biochemical and molecular characterization of purified chicken pancreatic phospholipase A2. Febs J 2009, 276(16):4545-4554.

39. de Haas GH, Postema NM, Nieuwenhuizen W, van Deenen LL: Purification and properties of an anionic zymogen of phospholipase A from porcine pancreas. Biochim Biophys Acta 1968, 159(1):118-129.

40. Fleer EA, Puijk WC, Slotboom AJ, de Haas GH: Modification of arginine residues in porcine pancreatic phospholipase A2. Eur J Biochem 1981, 116(2):277-284.

41. Scott DL, Otwinowski Z, Gelb MH, Sigler PB: Crystal structure of beevenom phospholipase $\mathrm{A} 2$ in a complex with a transition-state analogue. Science 1990, 250(4987):1563-1566.

42. Verger R, Mieras MC, de Haas GH: Action of phospholipase A at interfaces. J Biol Chem 1973, 248(11):4023-4034.

43. Evenberg $A$, Meyer $H$, Verheij HM, de Haas GH: Isolation and properties of prophospholipase A2 and phospholipase A2 from horse pancreas and horse pancreatic juice. Biochim Biophys Acta 1977, 491(1):265-274.

44. Nieuwenhuizen W, Steenbergh P, de Haas GH: The isolation and properties of two prephospholipases A2 from porcine pancreas. Eur $J$ Biochem 1973, 40(1):1-7.

45. de Haas GH, Bonsen PP, Pieterson WA, van Deenen LL: Studies on phospholipase $A$ and its zymogen from porcine pancreas. 3 . Action of the enzyme on short-chain lecithins. Biochim Biophys Acta 1971, 239(2):252-266.

46. Scott DL, Sigler PB: Structure and catalytic mechanism of secretory phospholipases A2. Adv Protein Chem 1994, 45:53-88.

47. Scott DL, Sigler PB: The structural and functional roles of calcium ion in secretory phospholipases A2. Adv Inorg Biochem 1994, 10:139-155.

48. Bacha $A B$, Gargouri $Y$, Bezzine $S$, Mejdoub H: Purification and biochemical characterization of phospholipase A2 from dromedary pancreas. Biochim Biophys Acta 2006, 1760(8):1202-1209.

49. Bradford MM: A rapid and sensitive method for the quantitation of microgram quantities of protein utilizing the principle of protein-dye binding. Anal Biochem 1976, 72:248-254.

50. Laemmli UK: Cleavage of structural proteins during the assembly of the head of bacteriophage T4. Nature 1970, 227(5259):680-685.

51. Chomczynski P, Sacchi N: Single-step method of RNA isolation by acid guanidinium thiocyanate-phenol-chloroform extraction. Anal Biochem 1987, 162(1):156-159
doi:10.1186/1476-511X-10-27

Cite this article as: Karray et al.: Purification and biochemical

characterization of a secreted group IIA chicken intestinal

phospholipase $A_{2}$. Lipids in Health and Disease 2011 10:27.

\section{Submit your next manuscript to BioMed Central and take full advantage of:}

- Convenient online submission

- Thorough peer review

- No space constraints or color figure charges

- Immediate publication on acceptance

- Inclusion in PubMed, CAS, Scopus and Google Scholar

- Research which is freely available for redistribution 